\title{
A Jeremiad for Ben: Things Fall Apart
}

\author{
Scott G. McNall
}

\begin{abstract}
This contribution honors the memory and work of our friend and colleague Ben Agger who died in July 2015. Ben would have had a lot to say about the 2016 campaign and its shocking result---the election of Donald Trump to the Presidency. The following is written in the spirit of his later writings, which were provocative and forceful but grounded always in critical theory. This is what I imagine he might have said and the counsel he might have offered us.
\end{abstract}

The day after Trump's victory, two flyers landed on doorsteps in Missoula, Montana. One flyer decried Jewish control of the media; the other demanded "Free Healthcare for the White Working Class." [1] Both flyers were from the American Nazi Party. Both are revealing. Trump had promised throughout his campaign that he was going to end Obamacare, yet here were some of his supporters asking for something that President Obama and the Democratic Party had been attempting to implement for years---universal health care. In this case, though, the Nazis wanted universal and free health care just for white people. The second flyer simply amplified what Trump had claimed throughout the campaign and would continue to claim---the "crooked" media were against him. The Nazis added the fillip that it was the Jewish media that sought to undo the manly Trump.

Manliness was an issue in the campaign. A poll conducted by the Public Religion Research Institute found that $50 \%$ of all men felt that society was becoming too soft and feminine, while $74 \%$ of Trump supporters believed this. Trump supporters were also most likely $(65 \%)$ to say that what the country needed was a leader who would break the rules.[2] Trump had the endorsement of the National Rifle Association and assured his supporters that their guns would never be taken away from them. Trump voters wanted a declared tough guy.

There is no way to pretty up the face of some of the forces that carried Trump to victory. He consistently legitimated racism, homophobia, misogyny (that "nasty" woman), and xenophobia. He claimed a right to manhandle women's body parts because of his fame, insisted that climate change was a hoax perpetrated by the Chinese, promised to undo regulations that limited the use of fossil fuels, get tough with our enemies, renegotiate trade deals, and so forth. Not everybody who voted for Trump was a racist, of course, but he was endorsed by the KKK and the more hysterical of the alt-right grandees, such as Steve Bannon, executive chairman of Brietbart News, a major source of right-wing paranoia. Bannon served as Chief Executive of Trump's campaign and was tapped by Trump to serve as his chief strategist and senior counselor in the White House. This is an ominous sign.

There are many ways to understand why the entire heartland of America turned red while the East and West Coasts, Indian reservations, and scattered college towns like Madison, Wisconsin, Missoula, Montana, Ann Arbor, Michigan, Columbus, Ohio and Lawrence, Kansas stood out as blue beacons of the left. Trump also took states that had long voted for Democrats---Iowa, Michigan, Ohio, Pennsylvania, and Wisconsin. Why the sweep? Let me list some of the factors.

Trump was and is a master of simultaneously mystifying and simplifying the complex nature of both the global economy and the way in which our political system actually works. He promised better "deals" on treaties and trade agreements without any apparent understanding of how Congress works and laws are made. Never mind. His supporters thought that with a stroke of his pen a new economic dawn would break. Like the demagogue Huey Long before him, he promised a chicken in every pot.[3] He promised workers at a Carrier plant in Indiana that he would stop Carrier from moving to Mexico and save 1400 good-paying jobs. What he "saved" was a total of 730 jobs after Carrier received credit for 300 administrative and engineering jobs that were never intended to be sent to 
Mexico and after the state of Indiana promised $\$ 7$ million in tax breaks for the company. Carrier, however, then proceeded to close another Indiana plant shifting 1000 jobs to Mexico. [4] He promised that coal jobs would return to Appalachia. Did any of his followers understand that the vast majority of coal jobs have disappeared because of automation? That coal is dwindling as a percentage of our energy supply because natural gas is cheaper? Did Trump even know?

Trump claimed he was the master of "The Art of the Deal." And most of his supporters wanted in on the deal! Never mind how he got his money, or the fact that he is notorious for going bankrupt, stiffing the little person; they want in. Trump, of course, represents a distorted version of the American Dream of working hard and moving up in the world. He may or may not have worked hard but he started with an elite education, inherited riches and connections from his father that gave him a head start the average American doesn't have. They bought his braggadocio that he alone had built his fortune, whatever it proves to be.

Trump's support came from a deep-rooted backlash, long in the making. Few remember Seattle in 1999, the first and largest demonstration in the U.S. against the World Trade Organization (WTO), globalization, the destruction of the environment, and the loss of jobs to low-waged countries. Anarchists marched with environmentalists; labor activists and union members joined their ranks. The broad-based coalition represented divergent class interests, all aligned against what was perceived to be an international corporate elite that did not respect nationhood. The reality, however, was that despite continued mobilization against it, globalization and its handmaiden, finance capital, would continue apace. Bill Clinton's presidency began with a full-court press to develop a neoliberal agenda---a middle way---for the U.S. Clinton removed restrictions on banks by repealing the Glass-Steagall Act, in place since 1933, designed to prevent banks from engaging in risky behavior. Some believe repeal of the act led to the ultimate collapse of banks and the need to bail out those too "big to fail," in 2008. Ordinary people lost the value they had tied up in the homes; some lost everything. Did anybody go to jail for the crimes committed against the American people? The answer is well known: No! And those who suffered have not forgotten.

A lot of steam was taken out of protests that had been building against globalization when the 9/11 attacks occurred and we went to war. We have now been at war for 15 years and there is really no end in sight. Trump claims he is going to build up our military strength---we will not be kicked around anymore! Like President Nixon's Vice President, Spiro Agnew, he intends to bomb to oblivion Muslims he has labeled as "savages." Yet, we have already squandered national resources and international prestige in our attempts to "bring democracy" to the Middle East. Many of those men and women who chose to fight in our wars have come home bitter from what some of them considered to be an unwinnable war; and some have found themselves homeless in America. Meanwhile, these wars took attention away from problems important to working Americans.

Working Americans' fears of globalization were stoked in the 2000 campaign by the paleoconservative, Pat Buchanan, running on the Reform Party ticket. His campaign bore a striking resemblance to that of Trump-proAmerica, anti-trade, tax cuts for the rich; in short, a form of right-wing populism. The populist position of Trump is not a class-based populism; it cuts across diverse groups of Americans, although its energy comes primarily from whites in small towns, rural areas, and those in America's rust belt. It is isolationist and it looks backward to an imagined "The Waltons," or a "Little House on the Prairie," past. It celebrates family, faith, and the American flag. It is a rejection of cosmopolitanism, corporate and government elites, and everybody who is not a white American.

Let us not forget the role of Bernie Sanders in all this. It is important to understand that in some respects his appeal to voters, primarily young and diverse Americans, was not totally dissimilar to Trump's appeal to whites. Trump promised to "drain the swamp" of Washington lobbyists and career politicians. Sanders raged against entrenched elites who were the paid hacks of powerful corporations. He promised college students a free education and universal health care for everyone. He promised to stop the Trans Pacific Partnership (TPP) in its tracks, because it would ship American jobs overseas. Trump and Sanders were crafting their own utopian visions for America---one looked backward, the other forward.

And then there is Hillary. As a number of progressives have pointed out, the wave of Sanders' supporters told us that Clinton was a flawed candidate. Yes, she was one of the most eminently qualified people to ever stand for the presidency. Yes, her candidacy was weakened by Russian interference in our national election with the help of Wikileaks; James Comey, director of the FBI, shipwrecked her candidacy with his 11th hour letter to Congress, and then a retraction too late to help her. Nevertheless, Clinton had real baggage. She was a career politician; she represented the status quo; she supported neo-liberal economic policies; and was embroiled in concerns about the Clinton Foundation. The relentless Republican attacks took their toll, but in fact she did not offer a vision, utopian or not, about what "stronger together" might actually mean. Why else would even 8\% of the African American 
vote in Florida go to Trump? As he said to African-Americans, "what do you have to lose by voting for me?" The national media also deserve some of the blame for her defeat. By focusing on the outrageous behavior of Trump they failed to do their job to help voters understand just how impossible to implement some of his claims were. As the hedge-fund manager Peter Thiel put it, Trump's voters took Trump seriously but not literally while the media took him literally, but not seriously.

The polls leading up to the election, wrong as they were about who would win, held ominous portents. White people now embrace a victimhood status. Men, especially, imagine themselves to be victimized by women, immigrants (for taking away their jobs), anybody who was "cutting in line" ahead of them. As Arlie Hochschild explains in her Strangers in Their Own Land, people have been drawn to groups like the Tea Party and have frequently voted against their class interests simply because they believed they had been good, patriotic, Americans.[5] They have worked hard and placed value on family and faith. They had been waiting patiently in line for their turn, and then seen the Federal government reaching a hand out to those in the back of the line---minorities, immigrants, Black Lives Matter protesters---people not like them. It simply wasn't fair. Trump played to these sentiments. Much to the shock of the intellectuals and the wealthy, anger was deep and broad. Cultural conservatives, including Evangelicals, crossed their fingers and voted for Trump because he told them the game was rigged and he was going to fix that. For a number of Americans, the cultural wars were not over; they deeply resented political correctness, special protections for the LGBT community, and challenges to their religious beliefs.

There were also the facts on the ground. Wages had stagnated for the working and middle-classes. Fifty-eight percent of all income growth was going to the top $1 \%$ of income earners. Wealth gaps had deepened; college costs were increasingly taking a larger share of a family's budget; white middle-aged American's health was declining; and opiate and drug addiction was destroying families and communities. The state was not protecting its people. Exit polls found that $72 \%$ of Americans-whether Democrats, Independents, or Republicans-agreed the economy is rigged to the advantage of the rich and powerful, and a full $57 \%$ said they don't identify with what America has become.[6]

As reporters fanned out across America to find out why people had voted for Trump, even when many of his positions clashed with their own values, one respondent said, "I feel the American people are at the point where they've had it, and this was the last chance." [7] A number of union members rejected the advice of their leadership and voted for Trump. Voters in Ohio, Pennsylvania, and Michigan who had voted for Obama in 2004 and 2008 went for Trump. The reason they gave for switching was simple: Obama had promised Change, with a capital C, but from their perspective little had changed---finance capital was triumphant, jobs continued to vanish, the rich were getting richer. The Washington elite had failed them. It was time for an outsider, no matter how bizarre some of his ideas and behavior were.

It is important to understand that votes against globalization and change are not a vote against capitalism. They are not even a rejection of the capitalist state. Rather they are a vote for what William Davies has termed a protectionist state.[8] People want the state to take care of them, not immigrants, or people of color, or women who chose abortion. They don't want the state to privilege people who are not them. This election was about a country at the end of empire and a last gasp attempt to restore it to an imagined past. The Republican Party, whose policies and practices are at variance with the social and economic desires of their new party members, now has to figure out how to embrace their cause. Will it? It is more likely we will see a protracted and messy clash between what Trump promised and what a House and Senate controlled by Republicans is willing to give.

Predicting what Trump will do is hard, given the erratic nature of his behavior and his mid-night attempts at policy making via Twitter. In the first month of his administration we witnessed chaos and attempts to seek revenge on anybody who had not supported him during the primaries or the general election. His appointment of Stephen Bannon, Kellyanne Conway, and Sean Spicer to critical positions in the White House signaled his desire to control all decisions and to continue to push a toxic message of racism and xenophobia. His advisers were happy to support his fantasies with "alternative facts" that his inaugural crowd was bigger than anybody else's; that his electoral win was the greatest since Reagan; that he would have won the popular vote if millions of illegal immigrants had not voted for Clinton; and so on. When the main-stream media challenged these "facts," Trump claimed they were being "so unfair," and that they were the ones, not his team, pushing "fake news."

His assault on the body politic continued in other ways. He nominated people for cabinet posts to oversee programs they had spent their careers attacking, or appointed people to positions who had no clue or experience managing such a division. Even Ben Carson expressed bemusement as to why he had been nominated to head up HUD (Housing and Urban Development.) Trump's initial budget plans also reveal mean-spiritedness. Though it 
would save only an infinitesimal amount, he proposed eliminating the National Endowment for the Humanities and funds for public radio. After all, who among his followers needed these?

Trump's personality is such that he cannot, apparently, brook any challenge to his authority or brilliance. He alone knows what needs to be done in the Middle East. He is a brilliant Commander in Chief who will develop new strategies for engagement. If Obama left him with an improved economy, he'll take credit for it. He has already taken credit for the jobs to be created by corporations already planning to expand their U.S. operations. As one cartoonist portrayed him, he is a cock crowing on the dung heap in the morning, taking credit for the sun rising.

There are two ways change can go in the near future. One is that the massive contradictions in what Trump has promised and what he can deliver to ordinary citizens will cause his base of support to wither. The contradictions between Trump's positions and those of the standard bearers of the Republican Party could contribute to a rollback of the Republican stranglehold on the body politic in midterm elections. But we should not count on this.

The other way change can go is mass mobilization of the left to reform the Democratic Party and the Democratic Central Committee. The good news is that resistance was rapid in coming. The day after the inauguration millions of women across America marched protesting Trump's election. The day Trump's Executive Order came barring refugees and citizens from seven Muslim countries, protests and marches broke out at airports across the country. The ACLU saw donations climb in one month by seven-fold. Planned Parenthood donations increased. Scientists marched in support of facts. This is a battle that will engage many Americans, some who have never been involved before, but it is one that has the potential not only to revive an agenda focused on equity but one that helps to build a sense of community and purpose.

We are back to where some of us started in the 1960s, with an uphill fight worth embracing across class lines. We need to continue to fight for social justice and be clear why a neoliberal regime is not going to deliver it or economic prosperity to the majority of Americans. We need to explain in every possible forum that tax cuts for the rich have never translated into economic growth or prosperity; on the contrary. We cannot let the gains achieved by environmental or social justice groups be rolled back. Above all we need to know that by sticking together we can create the kind of change we want.

\section{Endnotes}

1. Keila Szpaller. November 12, 2016. "Nazi Party Fliers in Missoula." Missoulian. A1-2.

2. Donald Cox and Robert P. Jones. April 7, 2016. "Twothirds of Trump Supporters Say Nation Needs a Leader Willing to Break the Rules." Public Religion Research Institute. Retrieved on November 14, 2016 at: http:// www.prri.org/research/prrithe-atlantic-survey-twothirds-trump-supporters-say-nation-needs-leaderwilling-break-rules/.

3. Nelson D. Schwartz. November 13, 2016. "Can Trump Save Their Jobs?” The New York Times. BU 1, 6-7.

4. Robert Sobel. December 1, 2016. "Donald Trump Played by Carrier as Second Plant Closing, 1000 Jobs Still Headed to Mexico. Blasting News. Retrieved on February 20, 2017 at: http://us.blastingnews.com/ news/2016/12/donald-trump-played-by-carrier-assecond-plant-closing-1-000-jobs-still-headed-tomexico-001300227.html.

5. Arlie Hochschild. 2016. Strangers in Their Own Land: Anger and Mourning on the American Right. New York: The New Press.
6. Cited in Thomas B. Edsall. November 13, 2016. "The Democratic Coalition's Epic Fail." The New York Times. SR 4.

7. Nelson D. Schwartz. November 13, 2016. "Can Trump Save Their Jobs?" BU,6.

8. William Davies. November 3, 2016. "Home Office Rules." London Review of Books, pp3, 6. 